\title{
HUBUNGAN PENGETAHUAN REMAJA USIA 17-20 TAHUN TENTANG KESEHATAN REPRODUKSI TERHADAP SIKAP BERPACARAN SEHAT DI KELAS III SMK 2 PAWYATAN DHAHA KEDIRI
}

\author{
Ira Titisari, Endrastuti Sulistyowati Utami \\ Prodi Kebidanan Kediri Jl.KH.Wakhid Hasyim 64 B Kediri \\ Email: iratitisari@ymail.com
}

\begin{abstract}
Abstrak
Social approach with the friends that are shown as serious affair is the stage of growth that adult will experience. This social approach can produce global information that will endanger producing good and qualifying adult. So, knowing and understanding of reproductive health is important to do in order not to make adult have bad attitude and behavior of serious affair.

The purpose of this study is to know The Relation of 17-20 year old Adult knowledge About Reroductive Health to The Attitude of Serious Affair in The Third Class of "SMK 2 pawyatan dhaha" Kediri. This study was held on july $19^{\text {th }}, 2008$. The design of this study is Cross Sectional Analitic. The population of this study is all 17-20 year old adults of the third class of "SMK 2 Pawyatan Dhaha" Kediri, they are 223 adults. The sampling technique we use is "Simple Random Sampling", so we get 143 adults as the sample. There are 2 variable, independent variable is the knowledge of 17-20 year old adult about reproductive health and dependent variable is the attitude of serious affair. The variables are measured in the same time with the instrument of study by using questioner.

We put the data that we get in a table then we are analized by using Chi Square with $\alpha 5 \%$. So, we can conclude the result of the study, that is "There are No Relation between the knowledge of 17-20 year old Adult About Reroductive Health to The Attitude of Serious Affair in The Third Class of "SMK 2 pawyatan dhaha" Kediri.
\end{abstract}

Keywords $\quad$ : Knowlwdge, adult, reproductive health, attitude, healthy serious affair

\section{Latar Belakang}

Masa remaja merupakan masa peralihan antara masa kanak-kanak dan masa dewasa, yang dimulai pada saat terjadinya kematangan seksual yaitu antara usia 11 atau 12 tahun sampai dengan 20 tahun, yaitu menjelang masa dewasa muda. Berdasarkan kematangan psikoseksual dan seksual, remaja akan melewati tahapan remaja awal (11-13 tahun ), remaja pertengahan ( 14-16 tahun ), dan remaja lanjut (17-20 tahun). Pada tahap remaja lanjut ini, remaja sudah mengalami perkembangan seperti orang dewasa. Mereka mempunyai perilaku seksual yang sudah jelas dan mereka mulai mengembangkannya dalam bentuk pacaran (Soetjiningsih, 2004). Berpacaran merupakan wujud dari interaksi sosial yang begitu kuat sebagai akibat dari pergaulannya dengan teman sebaya maupun masyarakat luas. Adanya interaksi sosial tersebut dapat memunculkan informasi global yang dapat mengancam terwujudnya remaja yang sehat dan berkualitas (PKBI, 1999). Oleh sebab itu remaja sebagai calon orang tua dan generasi penerus perlu dibekali dengan pengetahuan tentang kesehatan reproduksi agar mereka memiliki pengetahuan yang benar tentang sistem fungsi dan proses reproduksi manusia sehinggga kelak mereka 
secara bertanggung jawab dapat mempunyai keturunan yang sehat, cerdas, produktif dan mandiri. (Departemen Kesehatan RI dan WHO,1999)

Kesehatan reproduksi adalah suatu keadaan fisik, mental dan sosial secara utuh, bukan hanya bebas dari penyakit atau kecacatan dalam segala aspek yang berhubungan dengan sistem reproduksi. (Departemen Kesehatan RI dan WHO, 2000). Konsep tentang kesehatan reproduksi harus dimengerti oleh remaja agar tidak menimbulkan masalah-masalah kesehatan reproduksi misalnya, kehamilan remaja akibat hubungan seksual diluar nikah, HIV / AIDS, PMS dll. Menurut survei SKRRI 2002-2003, pengetahuan remaja tentang kesehatan reproduksi masih relatif rendah. Untuk usia 15-24 tahun pengetahuan laki laki hanya $46,1 \%$ dan pengetahuan perempuan hanya sekitar $43,1 \%$. Menurut Baseline survei 1999, diketahui hanya 55\% remaja yang mengetahui proses kehamilan dengan benar, $42 \%$ mengetahui tentang HIV/ AIDS dan hanya 24\% mengetahui tentng PMS, minimnya informasi remaja tersebut menimbulkan berbagai persoalan dikalangan remaja, mulai dari soal narkoba, HIV/AIDS, sampai hubungan seks pra nikah. (Beasiswa Indonesia, 2006)

Pengetahuan remaja tentang kesehatan reproduksi yang terbatas, seringkali mempengaruhi sikap dan perilaku remaja dalam berpacaran. Pada remaja yang berpacaran terdapat proses mengenal dan memahami lawan jenisnya dan belajar membina hubungan dengan lawan jenis, namun kebanyakan remaja salah mengartikan makna dari pacaran tersebut bahkan melenceng dari yang sebenarnya. Pacaran diperluas dengan interpretasi masing-masing bahkan tidak menjurus pada pacaran yang sehat. Pacaran sehat mempunyai arti pacaran yang terbebas dari segala bentuk kekerasan fisik ( termasuk biologis), kekerasan emosi dan pemaksaan atau penodaan fisik misalnya mencium, bercumbu dan berhubungan intim (Didik Hermawan, 2007). Hal-hal yang ditabukan remaja pada beberapa tahun yang lalu seperti berciuman dan bercumbu dalam berpacaran sekarang dibenarkan oleh remaja. Menurut penelitian Rita Damayanti di Jakarta ada beberapa remaja yang menyatakan bahwa berhubungan seks boleh saja dilakukan dengan pasangan asal disertai suka sama suka, ada yang tidak keberatan dengan pacaran saling berpegangan, saling berpelukan dan saling berciuman. Beberapa alasan antara lain adanya tekanan dari teman sebaya bahwa ciuman merupakan pambuktian cinta, sang pacar memaksa karena teman-temannya yang lain sudah pernah ciuman kemudian ingin tahu rasanya, terdapatnya nafsu, dan longgarnya control social (PKBI, 1999).

Dari data yang diperoleh dari tanya jawab di SMK 2 Pawyatan Dhaha Kediri dari 13 orang siswa kelas III mempunyai pacar dan mereka membenarkan bahwa 
berciuman,berpegangan tangan dan berpelukan perlu dilakukan saat berpacaran. Mereka juga mengatakan belum pernah mendapatkan pelajaran atau informasi tentang kesehatan reproduksi. Maka saya tertarik untuk melakukan penelitian dengan judul " Hubungan Pengetahuan Remaja Usia 17-20 tahun tentang Kesehatan Reproduksi terhadap Sikap berpacaran Sehat di kelas III SMK 2 Pawyatan Dhaha Kediri ".

\section{Perumusan Masalah}

"Adakah Hubungan antara Pengetahuan Remaja Usia 17-20 tahun tentang Kesehatan Reproduksi terhadap Sikap berpacaran Sehat di Kelas III SMK 2 Pawyatan Dhaha Kediri?"

\section{Tujuan Penelitian}

Tujuan Umum

Untuk mengetahui hubungan antara pengetahuan remaja usia 17-20 tahun tentang kesehatan reproduksi terhadap sikap berpacaran sehat di Kelas III SMK 2 Pawyatan Dhaha Kediri.

Tujuan Khusus

1. Untuk mengetahui pengetahuan remaja tentang kesehatan reproduksi.

2. Untuk mengetahui bagaimana sikap para remaja usia 17-20 tahun mengenai berpacaran sehat.

3. Untuk menganalisa hubungan antara pegetahuan remaja tentang kesehatan reproduksi terhadap sikap berpacaran sehat.

\section{Konsep Pengetahuan}

Pengertian pengetahuan

1. Pengetahuan adalah merupakan hasil tahu dan ini terjadi setelah orang melakukan pengindraan terhadap suatu objek tertentu.

2. Pengetahuan atau kognitif merupakan domain yang sangat penting dalam membentuk tindakan seseorang ( overt behavior ) (Soekidjo Notoatmodjo, 2003).

\section{Konsep Remaja}

Remaja adalah masa peralihan dari masa anak ke masa dewasa, meliputi semua perkembangan yang dialami sebagai persiapan memasuki masa dewasa (Gunarsa, 1999).

Dalam tumbuh kembang menuju dewasa berdasarkan kematangan psikoseksual dan seksual, semua remaja akan melewati tahapan berikut :

1. Masa remaja awal/dini : umur 11-13 tahun

Merupakan tahap awal/permulaan, remajasudah mulai tampak ada perubahan fisik yaitu fisik sudah mulai matang dan berkembang.

2. Masa remaja pertengahan : umur $14-16$ tahun

Pada masa remaja menengah, para remaja sudah mengalami pematangan fisik secara penuh yaitu anak laki-laki 
sudah mengalami mimpi basah sedangkan anak perempuan sudah mengalami menstruasi.

3. Masa remaja lanjut : umur $17-20$ tahun

Pada remaja akhir, remaja sudah mengalami perkembangan fisik secara penuh, sudah seperti orang dewasa. Mereka telah mempunyai perilaku seksual yang sudah jelas dan mereka sudah mulai mengembangkannya dalam bentuk pacaran.

(Soetjiningsih, 2004)

Karakteristik perkembangan remaja :

1. Perkembangan fisik-seksual

Ciri Seks Primer : Berkaitan langsung dengan organ seks misalnya pada remaja perempuan adalah Haid, pada remaja laki-laki mimpi basah.

Ciri seks sekunder : yang tidak berkaitan langsung dengan organ seks misalnya pada remaja perempuan membesarnya buah dada serta tumbuhnya rambut pada ketiak dan disekitar alat kelamin, sedang pada remaja laki-laki tumbuhnya jakun serta rambut diketiak dan disekitar alat kelamin.

(Departemen Kesehatan RI, 1999)

2. Perkembangan Psikososial

Dalam perkembangan sosial remaja, remaja mulai memisahkan dari orang tua memperluas hubungan dengan teman sebaya. Pada umumnya remaja menjadi anggota kelompok usia sebaya
( Peer Group ). Kelompok sebaya menjadi begitu berarti dan sangat berpengaruh dalam kehidupan sosial remaja (Soetjiningsih, 2004).

3. Perkembangan kognitif

Ditinjau dariperkembangan kognitif menurut Piaget, masa remaja sudah mencapai tahap operasi formal ( operasi sama dengan kegiatan-kegiatan mental tentang berbagai gagasan). Remaja secara mental telah dapat berpikir logis tentang berbagai gagasan yang abstrak.

4. Perkembangan emosional

Masa remaja merupakan puncak emosionalitas, yaitu perkembangan emosi yang tinggi. Pertumbuhan fisik, terutama organ-organ seksual mempengaruhi berkembangnya emosi atau perasaan - perasaan dan dorongandorongan baru yang dialami sebelumnya seperti perasaan cinta, rindu, dan keinginan untuk berkenalan lebih intim dengan lawan jenis.

5. Perkembangan moral

Perkembangan moral menurut Kusdwirarti Setiono ( Fuad Nashori, Suara Pembaharuan, 7 Maret 2097 ) pada umumnya remaja berada berada dalam tahap berperilaku sesuai dengan tuntutan dan harapan kelompok dan loyalitas terhadap norma atau peraturan yang berlaku dan diyakininya maka tidak heranlah jika diantara remaja masih banyak yang melakukan pelecehan nilai-nilai seperti tawuran, 
tindak kriminal minum minuman keras dan hubungan seks diluar nikah.

6. Perkembangan kepribadian

Fase remaja merupakan saat yang paling penting bagi perkembangan dan integrasi kepribadian.

( Syamsu Yusuf, 2005)

\section{Konsep Kesehatan Reproduksi}

Kesehatan reproduksi adalah keadaan sehat secara menyeluruh, mencakup fisik, mental, dan kehidupan sosial yang berkaitan dengan alat, fungsi, serta proses reproduksi (Departemen Kesehatan RI, 2000). Pengertian kesehatan reproduksi yang dirumuskan oleh Konferensi Internasional Kependudukan dan Pembangunan (ICDP) di Kairo tahun 1994 adalah keadaan kesejahteraan fisik, mental dan sosial yang utuh, dan bukan hanya tidak adanya penyakit atau kelemahan, dalam segala hal yang berhubungan dengan sistem reproduksi dan fungsi-fungsi serta proses-prosesnya. Pengertian sehat bukan semata-mata sebagai pengertian kedokteran (klinis), tetapi juga sebagai pengertian sosial. Seseorang dikatakan sehat tidak hanya memiliki tubuh dan jiwa yang sehat, tetapi juga dapat bermasyarakat secara baik. Kesehatan reproduksi bukan hanya masalah seseorang saja, tetapi juga menjadi kepedulian keluarga dan masyarakat.

(Yayasan Pelita Ilmu, 2008)
Faktor-Faktor yang Mempengaruhi

Kesehatan Reproduksi :

Secara garis besar dapat dikelompokkan empat golongan faktor yang dapat berdampak buruk bagi keseshatan reproduksi :

a. Faktor sosial-ekonomi dan demografi (terutama kemiskinan, tingkat pendidikan yang rendah dan ketidaktahuan tentang perkembangan seksual dan proses reproduksi, serta lokasi tempat tinggal yang terpencil);

b. Faktor budaya dan lingkungan (misalnya, praktek tradisional yang berdampak buruk pada kesehatan reproduksi, kepercayaan banyak anak banyak rejeki, informasi tentang fungsi reproduksi yang membingungkan anak dan remajakarena saling berlawanan satu dengan yang lain, dsb);

c. Faktor psikologis (dampak pada keretakan orang tua pada remaja, depresi karena ketidakseimbangan hormonal, rasa tidak berharga wanita terhadap pria yang membeli kebebasannya secara materi, dsb);

d. Faktor biologis (cacat sejak lahir, cacat pada saluran reproduksi pasca penyakit menular seksual, dsb).

(Juliandi Harahap, 2003)

\section{Konsep Sikap}

Sikap adalah memberi penilaian menerima atau menolak terhadap objek yang dihadapi dan biasanya pula berhubungan dengan suatu objek. 
Sikap adalah kecenderungan bertindak dari individu, berupa respon tertutup terhadap stimulus ataupun objek.

(Sunaryo, 2004)

Faktor yang mempengaruhi pembentukan sikap :

\section{Faktor internal}

Faktor ini berasal dari dalam diri individu. Dalam hal ini individu menerima, mengolah dan memilih segala sesuatu yang datang dari luar serta menentukan mana yang akan diterima dan mana yang tidak.Faktor internal mencakup fisiologis, psikologis dan motif.

2. Faktor Eksternal

Faktor ini berasal dari luar individu, berupa stimulus untuk membentuk dan mengubah sikap. Stimulus tersebut dapat bersifat langsung misalnya individu dengan individu, individu dengan kelompok. Dapat juga bersifat tidak langsung yaitu melalui perantara seperti alat komunikasi dan media massa baik elektronik maupun non elektronik. Faktor eksternal meliputi pengalaman, situasi, norma, hambatan dan pendorong (Sunaryo, 2004).

\section{Konsep Pacaran Sehat}

Pacaran sehat mempunyai arti pacaran yang terbebas dari segala bentuk kekerasan fisik (termasuk biologi), kekerasan emosi, pemaksaan atau penodaan fisik misalnya mencium, bercumbu dan berhubungan intim. (Didik Hermawan, 2007)

1. Sehat fisik

Sehat secara fisik berarti tidak tertularnya penyakit, tidak menyebabkan kehamilan yang tidak diinginkan, tidak menyakiti misalnya, saling memukul, menampar atau menendang, tidak merusak kesehatan orang lain.

2. Sehat Mental

Remaja berarti mempunyai nilai yang kuat, percaya diri, menguasai informasi tentang kesehatan reproduksi ( meliputi aspek fisiologis, moral, sosial dan psikologis ), mampu berkomunikasi, mampu mengambil keputusan dan siap atas segala resiko dari keputusan yang diambil.

3. Sehat Sosial

Mampu mempertimbangkan nilai-nilai dan norma yang ada dan berlaku dalam masyarakat dan juga remaja harus mempertimbangkan aspek agama yang melarang remaja melakukan aktivitas seksualitas termasuk sentuh menyentuh lawan jenis apalagi mengambil gaya pacaran yang tidak sehat seperti berpelukan, berciuman dan sampai hal yang paling jauh yaitu melakukan hubungan seks diluar nikah. (Ujang Hermawan, 2002)

4. Sehat seksual

Secara biologis, remaja mengalami perkembangan dan kematangan seks. 
Pacaran juga mempengaruhi kehidupan seksual seseorang. Kedekatan secara fisik dapat memicu timbulnya kontak fisik. Jadi dalam berpacaran harus saling menjaga dan mengendalikan diri masing-masing dengan tidak melakukan hal-hal yang beresiko.

5. Sehat Emosional

Hubungan yang baik akan terjalin apabila timbul rasa nyaman, aman, dan tentram, saling pengertian, saling terbuka, juga saling perhatian. Tidak cuma dituntut untuk mengenali emosi diri sendiri tapi juga memahami emosi orang lain. Yang lebih penting lagi adalah bagaimana bisa mengungkapkan dan mengendalikan emosi dengan baik. Dalam hal ini manajemen emosi harus ditata rapi. Yang jelas, tidak boleh melakukan kekerasan nonfisik kepada pacar misalnya marah-marah yang tidak jelas.

(Nilna Rahmi Isna, 2008)

\section{Populasi}

Populasi adalah setiap subjek (misalnya manusia, pasien) yang memenuhi kriteria yang telah di tetapkan. (Nursalam, 2003). Populasi dalam penelitian ini adalah remaja yang berumur 17-20 tahun di kelas III SMK 2 Pawyatan Dhaha Kediri sejumlah 223 orang.

\section{Sampel}

Sampel dalam penelitian ini adalah sebagian remaja dengan umur 17-20 tahun di kelas III
SMK 2 Pawyatan Dhaha Kediri. Untuk mengambil sampel dipergunakan rumus :

$n=\frac{N}{1+N(d)^{2}}$ diperoleh 143 responden

Keterangan :

$\mathrm{N}$ : jumlah populasi

$\mathrm{n}$ : jumlah sampel

$\mathrm{d}$ : tingkat signifikansi $(\mathrm{d}=0,05)$

\section{Sampling}

Teknik sampling adalah merupakan teknik pengambilan sample untuk menentukan sample yang akan digunakan dalam penelitian

( Sugiyono, 2006).

Sampling yang digunakan dalam penelitian ini adalah "Simple Random Sampling" yaitu teknik untuk pengambilan sample dengan cara acak. (Nursalam, 2003)

\section{Kriteria Sampel}

a. Kriteria Inklusi

Kriteria inklusi adalah karakteristik umum subjek penelitian dari suatu populasi target yang terjangkau yang akan diteliti. (Nursalam, 2003)

1. Remaja ( 17-20 tahun ) yang sekolah di kelas III SMK 2 Pawyatan Dhaha Kediri

2. Bersedia menjadi responden

b. Kriteria eksklusi

Adalah menghilangkan atau mengeluarkan subyek yang memenuhi kriteria inkusi dari suatu studi karena berbagai sebab (Nursalam, 2003). 
1.Remaja putri yang mengundurkan diri menjadi responden.

2. Remaja putri yang tidak masuk sekolah

\section{Variabel Penelitian}

Dalam penelitian ini terdapat dua variabel yaitu :

\section{Variabel Independen (Variabel Bebas)}

Variabel independen dalam penelitian ini adalah Dalam penelitian ini variabel bebasnya adalah pengetahuan remaja

17-20 tahun) tentang kesehatan reproduksi.

Variabel Dependen (Variabel Terikat)

Variabel dependen dalam penelitian ini adalah Dalam penelitian ini variabel tergantungnya adalah sikap berpacaran sehat.

\section{Analisa Data}

Untuk mengetahui hubungan antara 2 variabel maka peneliti melakukan analisa korelasi dengan rumus Chi-Square

$$
X^{2}=\sum \frac{(f o-f h)^{2}}{f h}
$$

( Arikunto, 2002 )

Keterangan :

$X^{2}=$ nilai Chi-Square / Chi kuadrat

fo $\quad=$ frekuensi yang diperoleh

berdasarkan data

fh $=$ frekuensi harapan

Untuk mencari fh :

$$
f h=\frac{\text { jumlah baris }}{\text { jumlah semua }} x \text { jumlah kolom }
$$

Setelah nilai $X^{2}$ ditemukan konsultasikan ke tabel dengan taraf signifikansi $5 \%$ dengan derajat bebas $=1$, sehingga menggunakan rumus :

$$
\begin{aligned}
\mathrm{Db} & =\left(\sum \text { baris-1 }\right)\left(\sum \text { kolom-1 }\right) \\
& =(2-1)(2-1) \\
& =1
\end{aligned}
$$

Untuk mengetahui kekuatan / derajat hubungan dapat dimasukkan ke dalam rumus koefisien kontingensi :

$C=\sqrt{\frac{X^{2}}{X^{2}+N}}$

Keterangan :

C : Koefisien kontingensi

$X^{2}$ : Chi kuadrat

$\mathrm{N}$ : jumlah sampel

(Arikunto, 2002)

Kesimpulan :

1. jika hasil $X^{2}$ hitung $\geq X^{2}$ tabel maka hipotesa diterima sehingga ada hubungan antara pengetahuan remaja usia 17-20 tahun tentang kesehatan reproduksi dengan sikap berpacaran sehat

2. Jika hasil $X^{2}$ hitung $\leq X^{2}$ tabel maka hipotesa ditolak sehingga tidak ada hubungan antara pengetahuan remaja usia 17-20 tahun tentang kesehatan reproduksi dengan sikap tentang berpacaran sehat.

\section{Hasil Penelitian}

1. Pengetahuan Remaja Usia 17-20 Tahun tentang Kesehatan Reproduksi di Kelas III SMK 2 Pawyatan Dhaha Kediri. 


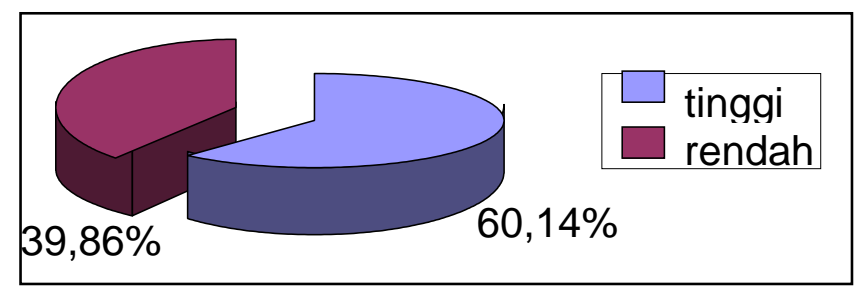

Diagram 1. Pengetahuan Renaja Usia 17-20 Tahun tentang Kesehatan Reproduksi

Dari diagram di atas dapat dijelaskan bahwa dari 143 siswa di Kelas III SMK 2 Pawyatan Dhaha Kediri selama penelitian diketahui bahwa prosentase pengetahuan remaja usia 17-20 tahun tentang kesehatan reproduksi didapatkan 86 responden berpengetahuan tinggi dan 57 responden berpengetahuan rendah.

2. Sikap Berpacaran Sehat Remaja Usia 17 - 20 Tahun di Kelas III SMK 2 Pawyatan Dhaha Kediri.

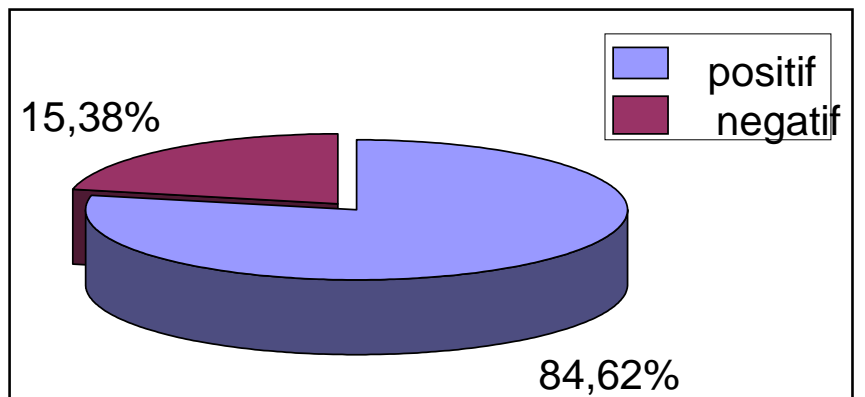

Diagram 2. Sikap Berpacaran Sehat Remaja Usia 17 - 20 Tahun

Dari diagram di atas dapat dijelaskan bahwa dari 143 siswa di kelas III SMK 2 Pawyatan Dhaha Kediri selama penelitian diketahui bahwa terdapat 121 responden bersikap positif untuk berpacaran sehat dan 22 responden bersikap negatif untuk berpacaran sehat
3. Pengetahuan Remaja Usia 17-20 Tahun tentang Kesehatan Reproduksi terhadap Sikap Berpacaran Sehat di Kelas III SMK 2 Pawyatan Dhaha Kediri.

Data yang didapatkan dari hasil penelitian sekitar 143 siswa di SMK 2 Pawyatan Dhaha Kediri adalah terdapat 70 responden yang berpengetahuan tinggi dan bersikap positif, 16 responden yang berpengetahuan tinggi dan bersikap negatif, 51 responden yang berpengetahuan rendah dan bersikap positif serta 6 responden yang berpengetahuan rendah dan bersikap negatif, sehingga dapat lebih dijelaskan lagi dalam tabel sebagai berikut :

Tabel 1. Distribusi Frekuensi Pengetahuan Remaja tentang Kesehatan Reproduksi terhadap Sikap Berpacaran Sehat

\begin{tabular}{|c|l|l|c|}
\hline No & Pengetahuan & Sikap Berpacaran Sehat & F \\
\hline 1 & Tinggi & Positif & 70 \\
2 & Tinggi & Negatif & 16 \\
3 & Rendah & Positif & 51 \\
4 & Rendah & Negatif & 6 \\
\hline & Jumlah & & 143 \\
\hline
\end{tabular}

Data di atas dianalisa dengan menggunakan rumus Chi Square sehingga didapatkan $x^{2}$ hitung sebesar 1,72. Tabel yang digunakan adalah 2 x 2 dengan derajat kebebasannya $5 \%$, maka didapatkan $x^{2}$ tabel 3,84. Harga kritik $x^{2}$ yang tertera dalam tabel ternyata lebih besar daripada $x^{2}$ hitung. Jadi, kesimpulannya tidak ada hubungan antara pengetahuan remaja usia 17-20 tahun 
tentang kesehatan reproduksi terhadap sikap berpacaran sehat di Kelas III SMK 2 Pawyatan Dhaha Kediri ( $\mathrm{HO}$ diterima ).

\section{Pembahasan}

1. Pengetahuan Remaja Usia 17-20 Tahun tentang Kesehatan Reproduksi di Kelas III SMK 2 Pawyatan Dhaha Kediri.

Dari diagram 4.1 mengenai Pengetahuan Remaja Usia 17-20 tahun tentang Kesehatan Reproduksi di Kelas III SMK Pawyatan Dhaha Kediri pada umumnya tinggi. Hal ini dapat dibuktikan dari jawaban responden melalui angket. Dari 143 responden terdapat 60,14\% responden mempunyai pengetahuan tinggi dan 39,86\% rsponden mempunyai pengetahuan rendah.

Dari $60,14 \%$ reponden yang berpengetahuan tinggi, sebagian besar menyatakan bahwa seseorang remaja perlu mengetahui tentang kesehatan reproduksi karena menjadikan remaja tumbuh menjadi orang dewasa yang sehat secara seksual. Sedangkan dari 39,86\% responden yang mempunyai pengetahuan rendah, sebagian besar menjawab salah mengenai arti kesehatan reproduksi. Menurut mereka kesehatan reproduksi merupakan suatu kemampuan seseorang untuk melanjutkan keturunan saja, padahal menurut Departemen Kesehatan RI, 2000 bahwa arti dari kesehatan reproduksi cukup luas yaitu keadaan sehat secara menyeluruh mencakup fisik, mental dan kehidupan sosial yang berkaitan dengan alat, fungsi, serta proses reproduksi

Tingginya pengetahuan siswa kelas III SMK 2 Pawyatan Dhaha Kediri mungkin disebabkan karena mereka memperoleh informasi kesehatan reproduksi melalui media elektronik atau media cetak, masalnya televisi, internet atau majalah. Informasi - informasi tersebut sangat mudah tersebar dan diterima remaja dengan cepat karena sebaian besar waktunya dihabiskan untuk melihat televise atau membaca Koran. Sedangkan sebagian kecil yang mempunyai pengetahuan rendah mungkin disebabkan karena kurang menyerap informasi tentang materi kesehatan reproduksi dan kurangnya keinginan serta motivasi untuk mencari informasi informasi mengenai kesehatan reproduksi.

Kondisi di atas sesuai dengan penjelasan dari Sonny K dan Mikhael D, 2001 bahwa faktor - faktor yang mempengaruhi pengetahuan seseorang adalah adanya informasi. Seseorang yang mempunyai pengetahuan berarti ia memang mempunyai data atau informasi yang akurat melebihi orang lain atau ketika orang lain tidak memiliki informasi seperti yang dimilikinya.

2. Sikap Berpacaran Sehat Remaja Usia 17-20 Tahun di Kelas III SMK 2 Pawyatan Dhaha Kediri 
Dari diagram 4.2 mengenai Sikap Berpacaran Sehat Remaja Usia 17-20 tahun di Kelas III SMK 2 Pawyatan Dhaha Kediri diperoleh 84,62 \% responden memiliki sikap positif dan $15,38 \%$ responden memiliki sikap negatif.

Dari 84,62 \% responden yang mempunyai sikap positif terhadap pacaran sehat, sebagian besar menyatakan mengerti dan memahami kesehatan reproduksi diperlukan saat berpacaran. Sedangkan dari15,38 \% yang mempunyai sikap negatif terhadap pacaran sehat, sebagian besar menyatakan bahwa berciuman, berpegangan tangan atau berpelukan saat pacaran penting dilakukan sebagai ungkapan rasa sayang. Sikap tersebut sudah melenceng dari konsep Didik Hermawan, 2007 mengenai pacaran sehat. Menurutnya pacaran sehat adalah pacaran yang terbebas dari segala bentuk kekerasan fisik (termasuk biologi), kekerasan emosi, pemaksaan atau penodaan fisik misalnya mencium, bercumbu dan berhubungan intim.

Sebagian besar siswa remaja usia 17-20 tahun di kelas III yang mempunyai sikap positif terhadap pacaran sehat kemungkinan disebabkan karena adanya pengaruh yang baik dari teman sebaya atau teman sekolah. Adanya teman sebaya tersebut sangat mempengaruhi remaja dalam bersikap dan berperilaku dalam kehidupan sehari -hari khususnya saat mereka menjalin hubungan khusus misalnya berpacaran. Sedangkan sebagian kecil remaja uisi 17-20 tahun di kelas III yang mempinyai sikap negatif terhadap pacaran sehat mungkin disebabkan karena faktor emosionalitas remaja. Masa remaja merupakan masa perkembangan emosi atau perasaan. Perasaan tersebut bisa berupa perasaan rindu, cinta dan keinginan untuk berkenalan lebih intim dengan lawan jenis. Biasanya perasaan seperti ini diwujudkan dengan berpegangan tangan, berciuman atau berpelukan saat pacaran sebagai ungkapan rasa sayang.

Sikap merupakan suatu kecenderungan bertindak dari individu, berupa respon tertutup terhadap stimulus ataupun objek. Respon tersebut bisa dalam bentuk menerima, mendekati, menyenangi, mengharapkan atau menolak, menjauhi, menghindari, membenci, tidak menyukai obyek tertentu. Adanya perbedaan sikap ini dipengaruhi oleh beberapa faktor, antara lain faktor internal ( dari dalam diri individu ) misalnya fisiologis, psikologis dan motif dan juga faktor eksternal ( dari luar individu ) misalnya, pengalaman, situasi, norma, hambatan dan pendorong ( Sunaryo, 2004 ). Dengan demikian adanya perbedaan sikap tersebut merupakan hal biasa yang harus dipahami sebagai bentuk keunikan tiap individu. 
3. Hubungan Pengetahuan Remaja Usia 17-20 Tahun tentang Kesehatan Reproduksi terhadap Sikap Berpacaran Sehat di kelas III SMK 2 Pawyatan Dhaha Kediri

Dari hasil perhitungan dan analisa data oleh peneliti dapat ditarik kesimpulan bahwa tidak ada hubungan antara pengetahuan remaja usia 17-20 tahun tentang kesehatan reproduksi terhadap sikap berpacaran sehat.

Hal ini menunjukkan bahwa sikap remaja Kelas III SMK 2 Pawyatan Dhaha Kediri untuk berpacaran sehat tidak dipengaruhi oleh pengetahuannya akan kesehatan reproduksi, tetapi dapat disebabkan oleh faktor- faktor lain misalnya, maraknya film - film dan majalah porno yang dapat mempengaruhi remaja dalam bersikap dan berperilaku atau dapat juga karena adanya pengaruh teman sebaya yang begitu kuat. Menurut Sunaryo, 2004 faktor - factor yang mempengaruhi sikap seseorang antara lain faktor yang berasal dari dalam individu. Dalam Hal ini individu menerima, menolak dan memilih segala sesuatu yang datang dari luar serta menentukan mana yang akan diterima dan mana yang tidak. Kemudian faktor dari luar individu, berupa stimulus yang bersifat langsung misalnya individu dengan individu. Dapat juga stimulus yang bersifat tidak langsung misalnya melalui perantara seperti alat komunikasi dan media masa baik elektronik maupun non elektronik .

Dapat disimpulkan bahwa seorang remaja dapat bersikap positif ataupun negatif terhadap sesuatu tidak hanya dipengaruhi oleh satu faktor saja melainkan dipengaruhi oleh banyak faktor. Hal ini dapat dikarenakan bahwa pada masa ini remaja sedang mengalami suatu perkembangan mental yang cukup rumit. Perkembangan tersebut saat mempengaruhi kehidupan sosial remaja. Keinginan untuk bereksperimen dan mencoba-coba merupakan salah satu bentuk perkembangan remaja yang juga sebagai faktor penghambat atau pendorong remaja untuk bersikap positif ( menerima ) ataupun bersikap negatif ( menolak ) terhadap suatu hal khususnya berpacaran sehat.

\section{Kesimpulan}

Dari hasil penelitian yang berjudul "Hubungan Pengetahuan Remaja Usia 17-20 Tahun tentang Kesehatan Reproduksi terhadap Sikap Berpacaran di Kelas III SMK 2 Pawyatan Dhaha Kediri" dapat ditarik kesimpulan sebagai berikut :

1. Secara Umum

Tidak ada hubungan antara pengetahuan remaja usia 17-20 tahun tentang kesehatan reproduksi terhadap sikap berpacaran sehat di Kelas III SMK 2 Pawyatan Dhaha Kediri.

\section{Secara Khusus}


a. Pengetahuan remaja usia 17-20 tahun tentang kesehatan reproduksi sebagian besar tinggi yaitu sekitar 60,84\%.

b. Sikap remaja usia 17-20 tahun mengenai berpacaran sehat adalah positif yaitu sekitar $84,62 \%$.

c. Tidak ada hubungan antara pengetahuan remaja usia 17-20 tahun tentang kesehatan reproduksi terhadap sikap berpacaran sehat.

\section{Saran}

Sesuai dengan hasil penelitian yang telah dilakukan, peneliti mengemukakan :

1. Bagi Tempat Penelitian

a. Diharapkan dibentuk suatu kegiatan pembinaan rohani di sekolah guna peningkatan keimanan dan ketaqwaan terhadap Tuhan Yang Maha Esa, membentuk moral yang kuat, dan menanamkan norma - norma yang berlaku di masyarakat.

b. Diharapkan sekolah dapat memberikan penyuluhan atau bimbingan tentang kesehatan reproduksi walaupun dalam kurikulum sekolah tidak ada.

2. Bagi peneliti selanjutnya

Diharapkan penelitian ini dapat dijadikan sebagai bahan acuan untuk penelitian selanjutnya dengan mengubah factor lain, misalnya hubungan pengetahuan remaja tentang perkembangan seksualitas remaja terhadap sikap berpacaran sehat.

\section{DAFTAR PUSTAKA}

Beasiswa Indonesia. ( 2006 ). Lomba Karya Ilmiah Remaja.
Available

http://beasiswa.wordpress.com/2006/1

1/17/lomba-karya-tulis-remaja, diakses jam 11.00, tanggal 9 April 2008

Departemen Kesehatan RI dan WHO. ( 1999

). Materi Inti Kesehatan Reproduksi Remaja. Jakarta : Departemen Kesehatan RI

Departemen Kesehatan RI. ( 2000 ). Kesehatan Reproduksi Remaja (KRR). Jakarta : Departemen Kesehatan RI

Departemen Pendidikan Nasional. (2002). Kamus Besar Bahasa Indonesia. Jakarta : Balai Pustaka

Didik Hermawan. (2007). Panduan Tuntas Masa Pubertas. Solo : Smart Media

Dinas Kesehatan Kota Kediri.(2006). Materi Inti Kesehatan Reproduksi Remaja. Jakarta : Dinas Kesehatan Kota Kediri

Glasier, Anna. (2006). Keluarga Berencana dan Kesehatan Reproduksi. Jakarta : EGC

Gunarsa. ( 2099 ). Psikologi Remaja. Jakarta : PT BPK Gunung Mulia

Heri Purwanto. (2099). Pengantar Perilaku Manusia. Jakarta : EGC

Juliandi Harahap. ( 2003 ). Kesehatan Reproduksi. Available http://libary.usu.ac.id/download/fk/ked komunitas Juliandi.pdf, tanggal 9 April 2008

Kasihani K dan E. Suyanto. ( 2007 ). Pendekatan Metode dan Teknik Pembelajaran. Malang : Badan Penyelenggara Startifikasi Guru Universitas Negeri Malang

Nilna Rahmi Isna. ( 2008 ). Pacaran Asal Sehat. Available http://nilna.wordpress.com/2008/01/11 /pacaran-asal-sehat, tanggal 9 April 2008

Nursalam. (2003). Konsep dan Penerapan Metodologi Penelitian Ilmu Keperawatan. Jakarta : Salemba Medika

Soekidjo Notoatmojo. ( 2002 ). Metodologi Penelitian. Jakarta : Rineka Cipta

Sonny Keraf dan Mikhael Dua. ( 2001 ). Ilmu Pengetahuan Sebuah Filosofis. Yogyakarta : Kanisius

PKBI. ( 1999 ). Potret Remaja Dalam Data. 
Available

http://geocities.com.id/guntoroutamadi

lartikel-potret-remaja-dalam-data.html, diakses jam 12.00, tanggal 9 April 2008

Soetjiningsih. (2004). Tumbuh Kembang Remaja dan Permasalahannya. Jakarta : EGC

Sugiyono. ( 2006 ). Metode Penelitian Administrasi. Bandung : ALFABETA

Suharsimi Arikunto.( 2002 ). Prosedur

Penelitian. Jakarta : Rineka Cipta

Sunaryo. (2004). Psikologi untuk

Keperawatan. Jakarta : EGC

Syamsu Yusuf. (2005). Psikologi

Perkembangan Anak dan remaja. Bandung : Rosda

Ujang Hermawan.(2002). Gaya Pacaran Ala Kota Banda Aceh.

Available

http://situs.kesrepro.info/krr/jun/2002/

krr04.htm, diakses jam 20.00, tanggal 9 April 2008

Yayasan Pelita Ilmu. ( 2008 ). Isu Kespro Remaja. Available : http://ypi.or.id/index/php?opt ion $=$ com_content \&task $=$ view \&id=46\&Itemid=97, tanggal $9 \quad$ April 2008 